\title{
Voluntary or mandatory training participation as a moderator in the relationship between goal orientations and transfer of training
}

Citation for published version (APA):

Gegenfurtner, A., Könings, K., Kosmajac, N., \& Gebhardt, M. (2016). Voluntary or mandatory training participation as a moderator in the relationship between goal orientations and transfer of training. International Journal of Training and Development, 20(4), 290-301. https://doi.org/10.1111/ijtd.12089

Document status and date:

Published: 01/12/2016

DOI:

10.1111/ijtd.12089

Document Version:

Publisher's PDF, also known as Version of record

Document license:

Taverne

Please check the document version of this publication:

- A submitted manuscript is the version of the article upon submission and before peer-review. There can be important differences between the submitted version and the official published version of record.

People interested in the research are advised to contact the author for the final version of the publication, or visit the DOI to the publisher's website.

- The final author version and the galley proof are versions of the publication after peer review.

- The final published version features the final layout of the paper including the volume, issue and page numbers.

Link to publication

\footnotetext{
General rights rights.

- You may freely distribute the URL identifying the publication in the public portal. please follow below link for the End User Agreement:

www.umlib.nl/taverne-license

Take down policy

If you believe that this document breaches copyright please contact us at:

repository@maastrichtuniversity.nl

providing details and we will investigate your claim.
}

Copyright and moral rights for the publications made accessible in the public portal are retained by the authors and/or other copyright owners and it is a condition of accessing publications that users recognise and abide by the legal requirements associated with these

- Users may download and print one copy of any publication from the public portal for the purpose of private study or research.

- You may not further distribute the material or use it for any profit-making activity or commercial gain

If the publication is distributed under the terms of Article 25fa of the Dutch Copyright Act, indicated by the "Taverne" license above, 


\title{
Voluntary or mandatory training participation as a moderator in the relationship between goal orientations and transfer of training
}

\author{
Andreas Gegenfurtner, Karen D. Könings, \\ Nikola Kosmajac and Markus Gebhardt
}

\begin{abstract}
Trainees can participate in organizational training programs voluntarily or mandatorily. To date, research has reported mixed evidence on the question whether voluntary or mandatory participation is associated with higher motivation and transfer of training. Grounded in the frameworks of participatory design, the notion of autonomy in basic psychological needs theory, and the $2 \times 2$ model of achievement goals, this meta-analysis examined the relationship between goal orientations and transfer of training in contexts of voluntary and mandatory training participation with a sample of $N=4729$ trainees in $k=29$ studies. Goal orientations were conceptualized in four dimensions: mastery-approach, mastery-avoidance, performance-approach, and performance-avoidance. Results of the primary metaanalysis indicated that mastery-approach orientation had the most positive correlation with transfer of training, followed by performance-approach, mastery-avoidance and performanceavoidance goal orientation. Meta-analytic subgroup analysis examined the effects of two conditions for training participation: voluntary participation and mandatory participation. The findings indicated that training participation significantly moderated the correlation coefficients of mastery-approach and performance-avoidance goal orientation, with more positive estimates when training enrollment was voluntary. Contrary to expectations, the correlation coefficient between performanceapproach goal orientation and transfer of training was more
\end{abstract}

$\square$ Andreas Gegenfurtner, Technische Hochschule Deggendorf, Edlmairstraße 9, 94469 Deggendorf, Germany. Email: andreas.gegenfurtner@th-deg.de. Karen D. Könings, Maastricht University, Universiteitssingel 60,6229 ER Maastricht, the Netherlands. Email: kd.koenings@maastrichtuniversity. nl. Nikola Kosmajac, University of Turku, Assistentinkatu 5, 20014 Turku, Finland. Email: nikkos@utu. fi. Markus Gebhardt, Technical University of Munich, Arcisstraße 21, 80333 Munich, Germany. Email: markus.gebhardt@tum.de 


\section{positive when entry into training programs was obligatory and mandated. Implications for future research and the practice of training design and delivery are discussed.}

\section{Introduction}

If trainees participate in a training program voluntarily, are they more motivated and do they transfer more than trainees who participate in a training program mandatorily (Baldwin et al., 1991; Curado et al., 2015)? This question can have implications for the design and delivery of human resource development programs in organizations worldwide. In an attempt of approaching an answer to this question, the present study aimed to examine if voluntary training participation results in more positive relationships between goal orientations and transfer than mandatory training participation. In the present study, transfer of training refers to the use of trained knowledge and skills back on the job (Burke \& Hutchins, 2007; Chiaburu \& Marinova, 2005; QuesadaPallarès \& Gegenfurtner, 2015).

\section{Goal orientations and transfer of training}

Goal orientations refer to individual tendencies that describe why individuals engage in task-related behavior (Dweck \& Leggett, 1988; Elliot \& McGregor, 2001; Fisher \& Ford, 1998; Gegenfurtner \& Hagenauer, 2013; Van de Walle et al., 2001). Many conceptualizations of goal orientations exist. The $2 \times 2$ framework of Elliot and McGregor (2001) offers a widely used conceptualization that differentiates four types of goal orientations: mastery-approach, mastery-avoidance, performance-approach and performance-avoidance goal orientations. A mastery-approach goal (sometimes labeled a task goal, learning goal or mastery-approach goal) refers to develop competence or to master tasks. A mastery-avoidance goal refers to avoid failing to develop competence or making errors in a task. A performance-approach goal (sometimes labeled an ability goal, ego goal or performance goal) refers to demonstrate normative competence for others. A performance-avoidance goal (sometimes labeled an avoidance goal or ego-defensive goal) refers to avoid showing normative incompetence. Training research demonstrated that goal orientations play an important role in the transfer process, both in supporting transfer and in hindering transfer. Transfer of training can be defined as the use of trained knowledge and skills on the job (for more detailed discussions on the notion of transfer, see Burke \& Hutchins, 2007; Gegenfurtner et al., 2009; Segers \& Gegenfurtner, 2013). How does transfer associate with mastery-approach, mastery-avoidance, performance-approach and performanceavoidance goal orientations?

Mastery-approach goal orientations are widely investigated. For example, a number of studies reported positive correlations between mastery-approach goals and transfer of training (e.g. Boyce et al., 2008; Chiaburu et al., 2010; Dragoni et al., 2009; Laine \& Gegenfurtner, 2013; Nordstrom et al., 1998; Tziner et al., 2007; Van de Walle et al., 2010; Wilson et al., 2002). A few studies also identified negative correlations between masteryapproach goal orientation and transfer (Holladay \& Quiñones, 2003), particularly in training programs that were mandated (Orvis et al., 2009; Towler \& Dipboye, 2001).

Mastery-avoidance goal orientations are still a novel concept. Consequently, only a small number of studies to date have included this construct (Vanthournout et al., 2015). Chiaburu and Marinova (2005) reported a positive correlation between masteryavoidance correlation and transfer of training, a correlation that was smaller than correlations of transfer with mastery-approach, performance-approach and performanceavoidance goal orientations. Steele-Johnson et al. (2010) as well as Pham et al. (2010) reported negative correlation estimates with transfer.

Performance-approach goal orientations are also widely addressed in training research. The available evidence suggests mixed findings. Some studies report positive correlations with transfer of training (e.g. Chiaburu \& Tekleab, 2006; Gist \& Stevens, 
1998; Heimbeck et al., 2003 Kozlowski et al., 2001). In contrast, other studies suggest negative correlations with transfer of training (e.g. Bell \& Kozlowski, 2002; Ford et al., 1998; Maurer et al., 2002; Rogers \& Spitzmueller, 2009).

Performance-avoidance goal orientations are typically reported to have a negative correlation coefficient with transfer of training (Bell \& Ford, 2007; Bell \& Kozlowski, 2008; Brett \& Van de Walle, 1999; Dierdorf et al., 2010; Schmidt \& Ford, 2003), although positive correlation estimates between performance-avoidance orientation and training outcomes are also documented (Chiaburu \& Marinova, 2005).

In summary, the available evidence on the relationships between goal orientations and transfer of training is mixed. Among the possible reasons for the mixed evidence are characteristics of the specific samples and measurement instruments used in each study, which can confound with the true score population correlation (Schmidt \& Hunter, 2015). Meta-analytic techniques can be used to inquire whether the different dimensions of goal orientations, after controlling for sampling error and error of measurement (Laine \& Gegenfurtner, 2013; Rosenthal \& Di Matteo, 2001; Schmidt \& Hunter, 2015), exhibit a stable positive or negative influence on transfer. Based on Elliot and McGregor's (2001) framework, it can be expected that approach goals are positively related to transfer while avoidance goals are negatively related to transfer. Although goal orientations are frequently addressed in the training literature, a systematic comparison of the goal orientation - transfer relationship under different participation conditions is missing. Without more evidence, it would be premature to conclude how the influence of mastery-approach, mastery-avoidance, performance-approach and performance-avoidance goal orientations would influence transfer of training when trainees enter training programs voluntarily or mandatorily.

\section{Voluntary and mandatory training participation}

A number of studies examined how voluntary vs. mandatory participation in training affect motivation and training outcomes. Although none of these studies examined goal orientations, these examinations are interesting because they can suggest trends in how training participation and enrollment influence motivational and transfer-related outcomes. The available evidence can be clustered in three groups: (1) studies supporting voluntary participation, (2) studies supporting mandatory participation and (3) studies indicating marginal differences. First, in a classic study, Hicks and Klimoski (1987) reported that trainees who perceived a high degree of freedom to enter training had more positive reactions and higher achievement scores after training compared to trainees who perceived little freedom in their decision to enroll. More recently, Curado et al. (2015) demonstrated that trainees who attended training voluntarily had higher levels of autonomous motivation to transfer than trainees for whom training was mandated. Also Cohen (1990), Baldwin et al. (1991), Clark et al. (1993), Mathieu et al. (1992), as well as Yardley (2003) reported more positive training motivation and training outcomes when entry into training programs was voluntary.

A second group of studies indicated that trainees benefitted more when training was mandated. For example, Baldwin and Magjuka (1991) as well as Tsai and Tai (2003) reported that a mandatory program status resulted in higher levels of training motivation compared to a voluntary program status. Cotterchio et al. (1998), as well Rynes and Rosen (1995) indicated that training was more effective when participants were assigned to training. The success of mandatory training participation is explained with the belief of trainees that obligatory training must be important (Baldwin et al., 1991; Tsai \& Tai, 2003).

A third group of studies suggested that training assignment (voluntary vs. mandatory) had little effect on training motivation and training outcomes. For example, Dysvik and Kuvaas (2008) reported zero correlations between mandatory or voluntary attendance with task performance. Van Dongen and colleagues (2008) examined training with a digital simulator. The findings suggested that, when training was voluntary, a small number of participants were willing to train, largely because trainees lacked time for training during regular working hours. Training time only marginally 


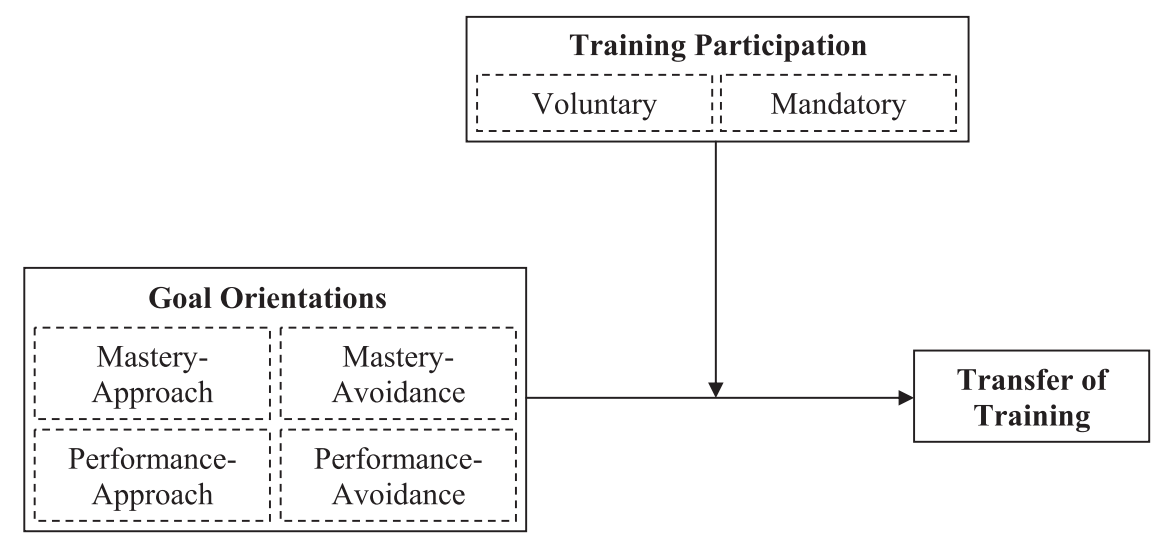

Figure 1: Graphical representation of the moderating effect of training participation on the relationship between goal orientations and transfer of training.

increased after introducing a competitive element and publically announcing individual training outcomes.

Positive effects of voluntary training participation can be explained with different theoretical frameworks, including participatory design research (e.g. Könings et al., 2014) and the notion of autonomy in basic psychological needs theory (Deci \& Ryan, 2012; Rosen et al., 2014). Participatory design refers to the involvement of the learner when learning environments are designed and implemented (Könings et al., 2014). The assumption is that being involved will increase engagement, motivation to learn and satisfaction with the learning environment. Conversely, if trainees have no choice or are uninvolved in training decisions, then this sense of not being heard can contribute to experiences of alienation, anonymity, and powerlessness (Könings et al., 2014). In addition to participatory design, also basic psychological needs theory (Rosen et al., 2014) highlights the motivating role of being involved. The assumption is that if learners feel autonomous in deciding whether to attend training or not, then this sense of autonomy and ownership results in higher levels of intrinsic motivation and contextual performance (Deci \& Ryan, 2012). If the assumptions from both theoretical frameworks are true, then the relationships between goal orientations and transfer of training can be expected to be more positive when trainees have a choice to attend. At the same time, previous findings tended to suggest that voluntary training participation is not always effective, largely because of time constraints and the belief that mandated training must be important. It is thus an empirical question to test the effects of training participation on achievement goals and transfer of training. An answer to this question can have profound implications for the design and delivery of training programs in human resource development.

\section{Study aims and hypotheses}

The aim of the study was to meta-analyze the extent to which four dimensions of goal orientations correlate with transfer of training. A second aim was to estimate the moderating effect of voluntary or mandatory training participation on the goal orientation transfer relationships. Figure 1 presents a graphical representation of the study aims. Eight hypotheses were formulated. First, and grounded in the $2 \times 2$ model of achievement goals (Elliot \& McGregror, 2001), transfer of training was expected to have positive correlations with mastery-approach (Hypothesis 1) and negative correlations with mastery-avoidance (Hypothesis 2) goal orientation; similarly, it was expected that transfer of training had positive correlations with performance-approach (Hypothesis 3 ) and negative correlations with performance-avoidance (Hypothesis 4) goal orientation. Second, and grounded in the theoretical notions of autonomy (Rosen et al., 2014) 
and participatory design (Könings et al., 2014), it was assumed that training participation would moderate the correlation coefficients. Particularly, the correlation estimates of training transfer with mastery-approach (Hypothesis 5), mastery-avoidance (Hypothesis 6), performance-approach (Hypothesis 7) and performance-avoidance (Hypothesis 8) goal orientations were expected to be more positive when participation in training was voluntary compared to mandatory.

\section{Method}

\section{Literature searches and criteria for inclusion}

To test this set of hypotheses, a psychometric meta-analysis of correlations using artifact distributions was performed following the procedures of Schmidt and Hunter (2015). Studies were included in the meta-analytic database if they reported a Pearson's correlation coefficient $r$ between one of the four dimensions of goal orientations (mastery-approach, mastery-avoidance, performance-approach, performance-avoidance) and transfer of training. Effect sizes other than Pearson's $r$ (such as Cohen's $d, F$, or $t$ ) were converted to $r$ using the formulae reported in Rosenthal and Di Matteo (2001). Literature was retrieved in two steps. In the first step, the PsycINFO, ERIC, Web of Science and Google Scholar databases were searched using the keywords goals, goal orientations, achievement goals, mastery orientation, learning orientation and avoidance in combination with transfer of training, training evaluation, training effectiveness, training application and training use of manuscripts published between the years 1985 and 2015. In the second step, reference lists from retrieved articles were cross-referenced to locate additional studies. The literature search resulted in a total of $k=29$ independent studies that contributed at least one effect size to the meta-analysis. Total sample size was $N=4729$ participants.

\section{Coding and tabulation of study information}

The following information was tabulated from the retrieved studies. First, coding included Pearson's $r$ of the goal orientation - transfer relationship, Cronbach's reliability estimate $\alpha$ of the independent variables (mastery-approach, mastery-avoidance, performance-approach and performance-avoidance goal orientation), and Cronbach's reliability estimate $\alpha$ of the dependent variable (transfer of training). The moderator variable (training participation) was coded as $0=$ mandatory participation and $1=$ voluntary participation. In addition, coding encompassed study characteristics and demographic characteristics, including first author, publication year, the number of participants $N$, their age (in years), and gender (percentage of females). Two independent and trained raters coded independently a random subset of three of the 27 studies. Because intercoder reliability was generally high, with a Cohen's $\kappa$ estimate of 0.96 , one rater continued to code the remaining studies.

\section{Meta-analytic procedures}

The meta-analytic procedures used in this study followed the methods of artifact distribution meta-analysis of correlations (Schmidt \& Hunter, 2015) because these methods provide an improvement from earlier statistical formulae when information such as reliability estimates is only sporadically reported in the original studies. Analysis occurred in two stages. In the first stage, a primary meta-analysis was performed to estimate the population correlation coefficient $\rho$ of the relationship between the different goal orientations and transfer of training. The distribution of Pearson's $r$ was corrected for sampling error, resulting in the corrected correlation estimate $r_{c}$. The distribution corrected for sampling error $r_{c}$ was then further corrected for error of measurement using the product of the compiled Cronbach's $\alpha$ reliability estimates of the independent and dependent variables, resulting in the population correlation coefficient $\rho$. In the second stage of the analysis, meta-analytic moderator estimation was performed using subgroup analysis to allow examination and reconciliation of 


\begin{tabular}{lcccccccccr}
\hline Dimension & $k$ & $N$ & $r$ & $r_{c}$ & $S D_{r c}$ & $\rho$ & $S D \rho$ & $\%$ Var & $95 \% C I$ & $80 \% C V$ \\
\hline Mastery-Approach & & & & & & & & \\
Voluntary & 17 & 2811 & 0.21 & 0.27 & 0.20 & 0.40 & 0.20 & 0.98 & $0.26 ; 0.28$ & $0.18 ; 0.62$ \\
Mandatory & 9 & 1439 & 0.12 & 0.12 & 0.19 & 0.18 & 0.19 & 0.99 & $0.11 ; 0.13$ & $-0.06 ; 0.42$ \\
All & 26 & 4250 & 0.18 & 0.20 & 0.19 & 0.30 & 0.19 & 0.99 & $0.19 ; 0.21$ & $0.06 ; 0.54$ \\
Mastery-Avoidance & & & & & & & & \\
Voluntary & 2 & 491 & 0.03 & 0.00 & 0.14 & 0.00 & 0.00 & 0.99 & $-0.01 ; 0.01$ & $0.00 ; 0.00$ \\
Mandatory & 1 & 256 & -0.08 & -0.08 & 0.00 & -0.11 & 0.00 & 1.00 & $-0.08 ;-0.08$ & $-0.11 ;-0.11$ \\
All & 3 & 747 & -0.01 & -0.03 & 0.12 & -0.04 & 0.00 & 1.00 & $-0.04 ;-0.02$ & $-0.04 ;-0.04$ \\
Performance-Approach & & & & & & & \\
Voluntary & 17 & 2428 & 0.00 & 0.01 & 0.15 & 0.01 & 0.21 & 1.00 & $0.00 ; 0.02$ & $-0.26 ; 0.28$ \\
Mandatory & 7 & 1113 & 0.02 & 0.04 & 0.07 & 0.06 & 0.08 & 0.99 & $0.04 ; 0.04$ & $-0.04 ; 0.16$ \\
All & 24 & 3541 & 0.01 & 0.02 & 0.13 & 0.03 & 0.19 & 0.99 & $0.02 ; 0.02$ & $-0.21 ; 0.27$ \\
Performance-Avoidance & & & & & & & \\
Voluntary & 8 & 1454 & -0.06 & -0.05 & 0.14 & -0.07 & 0.20 & 1.00 & $-0.06 ;-0.04$ & $-0.33 ; 0.19$ \\
Mandatory & 2 & 342 & -0.17 & -0.28 & 0.03 & -0.45 & 0.06 & 1.00 & $-0.28 ;-0.28$ & $-0.53 ;-0.37$ \\
All & 10 & 1796 & -0.08 & -0.10 & 0.17 & -0.15 & 0.24 & 0.99 & $-0.11 ;-0.09$ & $-0.46 ; 0.16$ \\
\hline
\end{tabular}

Note: $k$ is the number of data sources, $N$ is total sample size, $r$ is the uncorrected mean observed correlation, $r_{c}$ is the corrected mean observed correlation, $S D_{r c}$ is the standard deviation of the corrected mean observed correlation, $\rho$ is the population correlation coefficient, $S D_{\rho}$ is the standard deviation of the population correlation coefficient, $\%$ Var is the percentage of variance attributable to sampling error and error of measurement, $95 \% \mathrm{CI}$ is the $95 \%$ confidence interval around $r_{c}$, and $80 \% \mathrm{CV}$ is the $80 \%$ credibility interval around $\rho$.

differences in $\rho$ induced by training participation. Two subgroups were formed: one subgroup containing studies in which trainees attended the training voluntarily and one subgroup containing studies in which trainees attended the training mandatorily. Any study that did not explicitly report if trainees were free or mandated to participate was excluded from the meta-analysis. A criticism of the use of subgroups is that it reduces the number of studies per analysis, resulting in second-order sampling error. Although the present study contained a large number of data sources and participants, the possibility of second-order sampling error cannot be totally ruled out and is thus critically appraised when interpreting the findings (Schmidt \& Hinter, 2015).

\section{Results}

\section{Description of the included studies}

The 29 studies that were included in the analysis totaled 4729 participants. On average, participants were 28.52 years $( \pm 7.79)$ old. A total of 35.41 per cent $( \pm 26.82)$ of the sample was female. Training participation was voluntary in 20 studies (68.97 per cent) and mandatory in nine studies (31.03 per cent). A total of 26 studies examined masteryapproach goal orientation (89.66 per cent); three studies examined mastery-avoidance orientation (10.35 per cent); 24 studies examined performance-approach orientation (82.76 per cent); and 10 studies examined performance-avoidance orientation (34.48 per cent). Univariate analysis of variance across the four goal orientations indicated that trainee age and gender did not significantly differ between voluntary and mandatory training conditions.

\section{Results of the primary meta-analysis}

The primary meta-analysis corrected the correlation coefficients between goal orientations and transfer of training for sampling error and error of measurement. Table 1 reports the psychometric properties. The results indicate that mastery-approach 


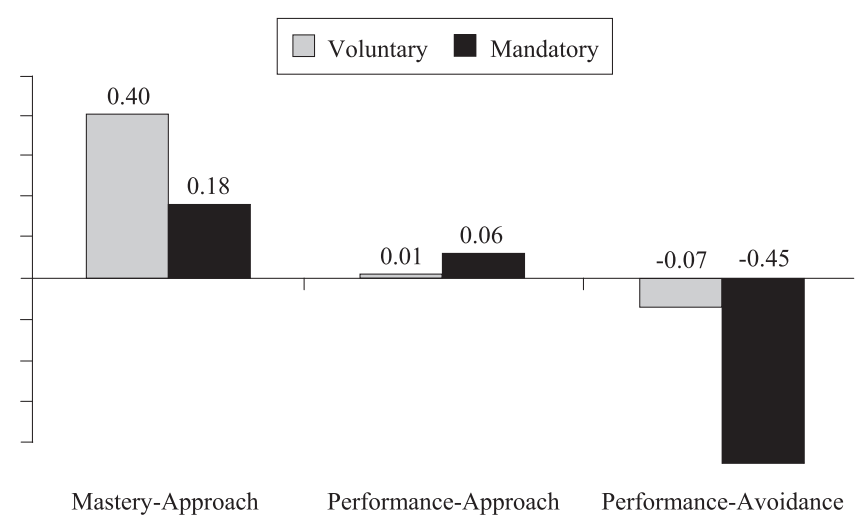

Figure 2: Population correlation coefficients $\rho$ by training participation.

orientation has a correlation of $\rho=0.30$ with transfer of training, which is more positive than the correlations of performance-approach $(\rho=0.03)$, mastery-avoidance $(\rho=-0.04)$, and performance-avoidance $(\rho=-0.15)$ goal orientation. These findings support Hypotheses 1-4. Table 1 also highlights that mastery-approach and performance-approach goal orientations are most frequently addressed in training research. In contrast, mastery-avoidance goal orientation is still a novel concept. Although it is frequently examined in the wider educational and educational psychological literature, mastery avoidance is less frequently addressed in research on training and development. Consequently, because it did not yet receive sufficient research attention, mastery-avoidance was excluded from the moderator analysis.

\section{Results of the meta-analytic moderator estimation}

Meta-analytic moderator estimation suggested that training participation significantly moderates the influence of goal orientations on transfer. Figure 2 presents an overview. First, the correlation between mastery-approach orientation and transfer is higher when training participation was voluntary $(\rho=0.40)$ compared with mandatory $(\rho=0.18)$. The difference is statistically significant, $t=34.51, S E=0.006, p<0.001$. This finding supports Hypothesis 5. Second, the correlation between performanceavoidance orientation and transfer is less negative when training participation was voluntary $(\rho=-0.07)$ compared with mandatory $(\rho=-0.45)$. The difference is statistically significant, $t=34.76, S E=0.011, p<0.001$. This finding supports Hypothesis 8. However, contrary to Hypothesis 7 , the correlation between performance-approach orientation and transfer of training is higher for mandatory $(\rho=0.06)$ compared with voluntary $(\rho=0.01)$ training participation, $t=7.69, S E=0.007, p<0.001$.

\section{Discussion}

The present meta-analysis had two aims. One aim was to psychometrically cumulate and correct individual study findings examining the relationship between goal orientations and transfer of training (Schmidt \& Hunter, 2015). For this purpose, goal orientations were conceptualized in four dimensions: mastery-approach, mastery-avoidance, performance-approach and performance-avoidance (Elliot \& McGregor, 2001). In support of Hypotheses 1-4, the meta-analytic evidence suggests that mastery-approach orientation had the highest, most positive correlation estimate with transfer, while performance-avoidance had the lowest, most negative correlation estimate. The magnitude of the correlations between performance-approach and mastery-avoidance orientation with transfer were negligible and close to zero. These findings highlight the important role of a mastery-approach goal orientation for influencing the use of trained knowledge and skills after training on the job. 
A second aim of the present meta-analysis was to estimate the extent to which voluntary or mandatory training participation moderated the goal orientation- transfer relationships (Baldwin et al., 1991; Curado et al., 2015; Gegenfurtner, 2011; Könings et al., 2014; Rosen et al., 2014). In support of Hypotheses 5 and 8, meta-analytic subgroup analyses suggested that the relationship between mastery-approach and performanceavoidance goal orientations with transfer of training were more positive when trainees participated by choice. These results tend to indicate that giving employees autonomy in their decision to participate in training programs is associated with more positive training outcomes. Surprisingly, the assumption that voluntary training participation would also result in more positive estimates for performance-approach orientation (Hypothesis 7) could not be confirmed; it seems that a social normative reference plays a minor role when choosing to participate in training programs. Test of Hypothesis 6 had to be postponed because cell sizes associated with the relationship between mastery-avoidance goals orientation and transfer of training were too small and did thus not warrant meta-analytic moderator estimation.

These findings have implications for future lines of inquiry. First, mastery-avoidance goal orientations need more research attention. Mastery-avoidance goals are conceptually distinct from performance-avoidance goals. Although both goal orientations share a negative valence (avoiding failure), they differ in the underlying definition of competence: mastery-avoidance goal orientations refer to avoid not mastering a task while performance-avoidance goal orientations refer to avoid that others notice one is not mastering a task (Elliot \& McGregor, 2001). For example, with regard to avoidance goals, training research can address perfectionist trainees who strive to avoid doing anything wrong (and so avoid transfer) or older trainees late in their careers who strive to avoid stagnating or performing not as good as early in their careers. Goal orientation research has developed a number of novel conceptualizations (e.g. Elliot et al., 2011, 2015; Gegenfurtner \& Hagenauer, 2013). These conceptualizations can be tested in training research to estimate how different goal orientations influence the initiation and maintenance of transfer activities under different participation and enrollment conditions. Another direction for future inquiry concerns participatory design in training research. This study addressed the choice to attend training (Curado et al., 2015; Hicks \& Klimoski, 1987; Tsai \& Tai, 2003; Yardley, 2003). Arguably, training assignment is an important factor (Baldwin \& Magjuka, 1991; Tsai \& Tai, 2003), but if we follow the premises of participatory design in research on learning and instruction, then it seems promising to evaluate how trainees can have their say also on other elements of the training program, including training content (Burke \& Hutchins, 2007), length (Laine \& Gegenfurtner, 2013), instructional format (Gegenfurtner et al., 2014), group composition (Gebhardt et al., 2015), participant age and expertise (Gegenfurtner \& Seppänen, 2013; Gegenfurtner \& Vauras, 2012), technology enhancement (Siewiorek \& Gegenfurtner, 2010; Siewiorek et al., 2013), mode of delivery (Gegenfurtner et al., 2013) or assessment conditions (Könings et al., 2014). Research bridging the gap between participatory design and human resource development is in its infancy and offers exciting avenues for future inquiry. A final direction for future research is associated with the motivational dimension under scrutiny. The present study was devoted to goal orientations. Based on the moderating effects discovered here, it would be fascinating to examine if similar patterns emerge with other motivational variables, including motivation to transfer (Curado et al., 2015; Gegenfurtner et al., 2009), transfer intentions (Gegenfurtner, 2013; Testers et al., 2015), individual and situational interest (Knogler et al., 2015) or task-related self-efficacy beliefs (Bell \& Kozlowski, 2008).

The study has implications for the practice of human resource development (HRD) officers and training designers. First, for HRD officers, the findings suggest that transfer of training seems more likely when trainees feel autonomous in deciding whether or not to attend training programs (Deci \& Ryan, 2012; Rosen et al., 2014). Thus, it seems plausible to recommend adopting a voluntary participation policy. Of course, there are situations in which particular knowledge and skills have to be trained, mandating enrollment. In those situations, offering options or choices for trainees to decide which program to attend, or when to attend it, can still help in supporting the trainee 
need of feeling autonomous and self-determined (Deci \& Ryan, 2012; Rosen et al., 2014). Second, for training designers, the results of this study indicate that learners benefit more from training when they can participate in the decision-making process associated with the training. This offers training designers the possibility to gather information on preferred training programs, to re-design existing curricula based on trainee preferences, and to involve trainees in implementing novel training formats within the organization.

Finally, this study has some limitations that should be noted. One limitation is associated with the fact that the population correlation estimates $\rho$ were corrected only for sampling error and error of measurement. The decision to correct for these artifacts was based on the frequent availability and reporting of sample size and reliability information. However, the original study reports might have been influenced by other biases as well (Schmidt \& Hunter, 2015). Therefore, the true population estimates of the goal orientation - transfer relationships may be somewhat larger than those reported here. Another limitation of the present study is that some cells contained a small number of studies, particularly in the case of mastery-avoidance and performance-avoidance orientations. Although correcting for bias on a small scale mitigates sampling error compared with uncorrected estimates in individual studies, the risk of second-order sampling error is acknowledged. This limitation can be addressed with more individual studies on the goal orientation - transfer relationship (Rosenthal \& Di Matteo, 2001; Schmidt \& Hunter, 2015). Finally, a third limitation refers to the conceptualization of goal orientations. The present study differentiated four dimensions of goal orientations. Alternative or more recent conceptualizations exist that would warrant inclusion (e.g. Elliot et al., 2015), as would an account of motivational constructs beyond goal orientations to examine their variance when training participation is voluntary or mandatory.

\section{Conclusion}

In summary, how can we answer the question stated in the beginning of this manuscript: if trainees participated in a training program voluntarily, are they more motivated and do they transfer more than trainees who participated in a training program mandatorily? An answer to this question can have important implications for those engaged with training design and delivery. Based on the present meta-analytic synthesis of 4 dimensions of goal orientations, 29 individual studies, 63 effect sizes, and 4729 trainees, the empirical answer tends to be: yes. It seems that offering trainees the choice to attend has a moderating effect on the relationship between goal orientation and transfer of training, with more positive estimates for mastery-approach and performance-avoidance orientation. If organizations decide to adopt a mandatory training policy, a performance-approach orientation tends to be supported, which in turn is less highly associated with transfer of training. It seems thus recommendable to offer enrollment in training programs on a voluntary basis - if practically possible and organizationally desirable. Future analyses are encouraged to extend the first steps reported here to the examination of how participatory design and feelings of autonomy can influence motivation and transfer in corporate training and development.

\section{References}

Baldwin, T. T. and Magjuka, R. J. (1991), 'Organizational training and signals of importance: Linking pretraining perceptions to intentions to transfer', Human Resource Development Quarterly, 2, 1, 25-36.

Baldwin, T. T., Magjuka, R. J. and Loher, B. T. (1991), 'The perils of participation: Effects of choice of training on trainee motivation and learning', Personnel Psychology, 44, 1, 51-65.

Bell, B. S. and Ford, J. K. (2007), 'Reactions to skill assessment: The forgotten factor in explaining motivation to learn', Human Resource Development Quarterly, 18, 1, 33-62.

Bell, B. S. and Kozlowski, S. W. J. (2002), 'Goal orientation and ability: Interactive effects on selfefficacy, performance, and knowledge', Journal of Applied Psychology, 87, 3, 497-505. 
Bell, B. S. and Kozlowski, S. W. J. (2008), 'Active learning: Effects of core training design elements on self-regulatory processes, learning, and adaptability', Journal of Applied Psychology, 93, 2, 296-316.

Boyce, L. A., LaVoie, N., Streeter, L. A., Lochbaum, L. E. and Psotka, J. (2008), ‘Technology as a tool for leadership development: Effectiveness of automated web-based systems in facilitating tacit knowledge acquisition', Military Psychology, 20, 4, 271-88.

Brett, J. F. and Van de Walle, D. (1999), 'Goal orientation and goal content as predictors of performance in a training program', Journal of Applied Psychology, 84, 6, 863-73.

Burke, L. A. and Hutchins, H. M. (2007), 'Training transfer: An integrative literature review and implications for future research', Human Resource Development Review, 6, 3, 263-96.

Chiaburu, D. S. and Marinova, S. V. (2005), 'What predicts skill transfer? An exploratory study of goal orientation, training self-efficacy and organizational supports', International Journal of Training and Development, 9, 2, 110-23.

Chiaburu, D. S. and Tekleab, A. G. (2006), 'Individual and contextual influences on multiple dimensions of training effectiveness', Journal of European Industrial Training, 29, 8, 604-26.

Chiaburu, D. S., Van Dam, K. and Hutchins, H. M. (2010), 'Social support in the workplace and training transfer: A longitudinal analysis', International Journal of Selection and Assessment, 18, 2, 187-200.

Clark, C., Dobbins, G. and Ladd, R. (1993), 'Exploratory field study of training motivation: Influence of involvement, credibility, and transfer climate', Group and Organization Management, 18, 3, 292-307.

Cohen, D. J. (1990), 'What motivates trainees?', Training and Development Journal, 44, 11, 91-3.

Cotterchio, M., Gunn, J., Coffill, T., Tormey, P. and Barry, M. A. (1998), 'Effect of a manager training program on sanitary conditions in restaurants', Public Health Reports, 113, 4, 353-8.

Curado, C., Lopes Henriques, P. and Ribeiro, S. (2015), 'Voluntary or mandatory enrollment in training and the motivation to transfer training', International Journal of Training and Development, 19, 2, 98-109.

Deci, E. L. and Ryan, R. M. (2012),'Motivation, Personality, and Development within Embedded Social Contexts: An Overview of Self-Determination Theory', in R. M. Ryan (ed.), Oxford Handbook of Human Motivation (Oxford: Oxford University Press), pp. 85-107.

Dierdorf, E. C., Brown, K. G. and Surface, E. A. (2010), 'Frame-of-reference training effectiveness: Effect of goal orientation and self-efficacy on affective, cognitive, skill-based, and transfer outcomes', Journal of Applied Psychology, 95, 6, 1181-91.

Dragoni, L., Tesluk, P. E. and Oh, I. (2009), 'Understanding managerial development: Integrating developmental assignments, learning orientation, and access to developmental opportunities in predicting managerial competencies', Academy of Management Journal, 52, 4, 731-43.

Dweck, C. S. and Leggett, E. L. (1988), 'A social-cognitive approach to motivation and personality', Psychological Review, 95, 2, 256-73.

Dysvik, A. and Kuvaas, B. (2008), 'The relationship between perceived training opportunities, work motivation and employee outcomes', International Journal of Training and Development, $12,3,138-57$.

Elliot, A. J. and McGregor, H. A. (2001), 'A $2 \times 2$ achievement goal framework', Journal of Personality and Social Psychology, 80, 3, 501-19.

Elliot, A., Murayama, K., Kobeisy, A. and Lichtenfeld, S. (2015), 'Potential-based achievement goals', British Journal of Educational Psychology, 85, 2, 192-206.

Elliot, A. J., Murayama, K. and Pekrun, R. (2011), 'A $3 \times 2$ achievement goal model', Journal of Educational Psychology, 103, 3, 632-48.

Fisher, S. L. and Ford, J. K. (1998), 'Differential effects of learner effort and goal orientation on two learning outcomes', Personnel Psychology, 51, 2, 397-420.

Ford, J. K., Smith, E. M., Weissbein, D. A., Gully, S. M. and Salas, E. (1998), 'Relationships of goal orientation, metacognitive activity, and practice strategies with learning outcomes and transfer', Journal of Applied Psychology, 83, 2, 218-33.

Gebhardt, M., Schwab, S., Krammer, M. and Gegenfurtner, A. (2015), 'General and special education teachers' perceptions of teamwork in inclusive classrooms at elementary and secondary schools', Journal of Educational Research Online, 7, 2, 129-46.

Gegenfurtner, A. (2011), 'Motivation and transfer in professional training: A meta-analysis of the moderating effects of knowledge type, instruction, and assessment conditions', Educational Research Review, 6, 3, 153-68.

Gegenfurtner, A. (2013), 'Dimensions of motivation to transfer: A longitudinal analysis of their influences on retention, transfer, and attitude change', Vocations and Learning, 6, 2, 187-205.

Gegenfurtner, A., Festner, D., Gallenberger, W., Lehtinen, E. and Gruber, H. (2009), 'Predicting autonomous and controlled motivation to transfer training', International Journal of Training and Development, 13, 2, 124-38. 
Gegenfurtner, A. and Hagenauer, G. (2013), 'Achievement goals and achievement goal orientations in education', International Journal of Educational Research, 61, 1, 1-4.

Gegenfurtner, A., Quesada-Pallarès, C. and Knogler, M. (2014), 'Digital simulation-based training: A meta-analysis', British Journal of Educational Technology, 45, 6, 1097-114.

Gegenfurtner, A. and Seppänen, M. (2013), 'Transfer of expertise: An eye-tracking and thinkaloud study using dynamic medical visualizations', Computers \& Education, 63, 1, 393-403.

Gegenfurtner, A. and Vauras, M. (2012), 'Age-related differences in the relation between motivation to learn and transfer of training in adult continuing education', Contemporary Educational Psychology, 37, 1, 379-93.

Gegenfurtner, A., Veermans, K., Festner, D. and Gruber, H. (2009), 'Motivation to transfer training: An integrative literature review', Human Resource Development Review, 8, 3, 403-23.

Gegenfurtner, A., Veermans, K. and Vauras, M. (2013), 'Effects of computer support, collaboration, and time lag on performance self-efficacy and transfer of training: A longitudinal metaanalysis', Educational Research Review, 8, 1, 75-89.

Gist, M. E. and Stevens, C. K. (1998), 'Effects of practice conditions and supplemental training method on cognitive learning and interpersonal skill generalization', Organizational Behavior and Human Decision Processes, 75, 2, 142-69.

Heimbeck, D., Frese, M., Sonnentag, S. and Keith, N. (2003), 'Integrating errors into the training process: The function of error management instructions and the role of goal orientation', Personnel Psychology, 56, 2, 333-61.

Hicks, W. and Klimoski, R. (1987), 'Entry into training programs and its effects on training outcome: A field experiment', Academy of Management Journal, 30, 3, 542-52.

Holladay, C. L. and Quiñones, M. A. (2003), 'Practice variability and transfer of training: The role of self-efficacy generality', Journal of Applied Psychology, 88, 6, 1094-103.

Knogler, M., Harackiewicz, J. M., Gegenfurtner, A. and Lewalter, D. (2015), 'How situational is situational interest? Investigating the longitudinal structure of situational interest', Contemporary Educational Psychology, 43, 1, 39-50.

Könings, K. D., Seidel, T. and van Merriënboer, J. J. G. (2014), ‘Participatory design of learning environments: integrating perspectives of students, teachers, and designers', Instructional Science, 42, 1, 1-9.

Kozlowski, S. W. J., Gully, S. M., Brown, K. G., Salas, E., Smith, E. M. and Nason, E. R. (2001), 'Effects of training goals and goal orientation traits on multidimensional training outcomes and performance adaptability', Organizational Behavior and Human Decision Processes, 85, 1, $1-31$.

Laine, E. and Gegenfurtner, A. (2013), 'Stability or change? Effects of training length and time lag on achievement goal orientations and transfer of training', International Journal of Educational Research, 61, 1, 71-9.

Mathieu, J. E., Tannenbaum, S. and Salas, E. (1992), 'Influences of individual and situational characteristics on measures of training effectiveness', Academy of Management Journal, 35, 4, 828-47.

Maurer, T. J., Mitchell, D. R. D. and Barbeite, F. G. (2002), 'Predictors of attitudes toward a 360degree feedback system and involvement in post-feedback management development activity', Journal of Occupational and Organizational Psychology, 75, 1, 87-107.

Nordstrom, C. R., Wendland, D. and Williams, K. B. (1998), “'To err is human": An examination of the effectiveness of error management training', Journal of Business and Psychology, 12, 3, $269-82$.

Orvis, K. A., Horn, D. B. and Belanich, J. (2009), 'An examination of the role individual differences play in videogame-based training', Military Psychology, 21, 4, 461-81.

Pham, N. T. P., Segers, M. S. R. and Gijselaers, W. H. (2010), 'Understanding training transfer effects from a motivational perspective: A test of MBA programmes', Business Leadership Review, 7, 1, 1-25.

Quesada-Pallarès, C. and Gegenfurtner, A. (2015), 'Toward a unified model of motivation for training transfer: A phase perspective', Zeitschrift für Erziehungswissenschaft, 18, S1, 107-21.

Rogers, A. and Spitzmueller, C. (2009), 'Individualism-collectivism and the role of goal orientation in organizational training', International Journal of Training and Development, 13, 3, 185-201.

Rosen, C. C., Ferris, D. L., Brown, D. J., Chen, Y. and Yan, M. (2014), 'Perceptions of organizational politics: A need satisfaction paradigm', Organization Science, 25, 4, 1026-55.

Rosenthal, R. and Di Matteo, M. R. (2001), 'Meta-analysis: Recent developments in quantitative methods for literature reviews', Annual Review of Psychology, 52, 1, 59-82.

Rynes, S. and Rosen, B. (1995), 'A field survey of factors affecting the adoption and perceived success of diversity training', Personnel Psychology, 48, 2, 247-70.

Schmidt, A. M. and Ford, J. K. (2003), 'Learning within a learner control training environment: The interactive effects of goal orientation and metacognitive instruction on learning outcomes', Personnel Psychology, 56, 2, 405-29. 
Schmidt, F. L. and Hunter, J. E. (2015), Methods of Meta-Analysis: Correcting Error and Bias in Research Findings, 3rd edn (Beverly Hills, CA: Sage).

Segers, M. and Gegenfurtner, A. (2013), 'Transfer of training: New conceptualizations through integrated research perspectives', Educational Research Review, 8, 1, 1-4.

Siewiorek, A. and Gegenfurtner, A. (2010), 'Leading to Win: The Influence of Leadership Style on Team Performance During a Computer Game Training', in K. Gomez, L. Lyons and J. Radinsky (eds), Learning in the Disciplines (Chicago, IL: International Society of the Learning Sciences), pp. 524-31.

Siewiorek, A., Gegenfurtner, A., Lainema, T., Saarinen, E. and Lehtinen, E. (2013), 'The effects of computer-simulation game training on participants' opinions on leadership styles', British Journal of Educational Technology, 44, 6, 1012-35.

Steele-Johnson, D., Narayan, A., Delgado, K. M. and Cole, P. (2010), 'Pretraining influences and readiness to change dimensions: A focus on static versus dynamic issues', Journal of Applied Behavioral Science, 46, 2, 245-74.

Testers, L., Gegenfurtner, A. and Brand-Gruwel, S. (2015), 'Motivation to Transfer Learning to Multiple Contexts', in L. Das, S. Brand-Gruwel, K. Kok and J. Walhout (eds), The School Library Rocks: Living It, Learning It, Loving It (Heerlen: IASL), pp. 473-87.

Towler, A. J. and Dipboye, R. L. (2001), 'Effects of trainer expressiveness, organization, and trainee goal orientation on training outcomes', Journal of Applied Psychology, 86, 4, 664-73.

Tsai, W. and Tai, W. (2003), 'Perceived importance as a mediator of the relationship between training assignment and training motivation', Personnel Review, 32, 2, 151-63.

Tziner, A., Fisher, M., Senior, T. and Weisberg, J. (2007), 'Effects of trainee characteristics on training effectiveness', International Journal of Selection and Assessment, 15, 2, 167-74.

Van de Walle, D., Brown, S. P., Cron, W. L. and Slocum, J. W. (1999), 'The influence of goal orientation and self-regulation tactics on sales performance: A longitudinal field test', Journal of Applied Psychology, 84, 2, 249-59.

Van de Walle, D., Cron, W. L. and Slocum, J. W. (2001), 'The role of goal orientation following performance feedback', Journal of Applied Psychology, 86, 4, 629-40.

Van Dongen, K. W., Van der Wal, W. A., Borel Rinkes, I. H. M., Schijven, M. P. and Broeders, I. A. M. J. (2008), 'Virtual reality training for endoscopic surgery: Voluntary or obligatory?', Surgical Endoscopy, 22, 3, 664-7.

Vanthournout, G., Kyndt, E., Gijbels, D. and Van den Bossche, P. (2015), 'Understanding the direct and indirect relations between motivation to participate, goal orientation and the use of self-regulation strategies during a formal training', Zeitschrift für Erziehungswissenschaft, 18, S30, 89-106.

Wierenga, M. (2010), On the Road to Developing Knowledge. A Study on the Effectiveness of Management Development Programmes (the Netherlands: University of Twente).

Wilson, P. H., Strutton, D. and Farris, M. T. (2002), 'Investigating the perceptual aspect of sales training', Journal of Personal Selling \& Sales Management, 12, 77-86.

Yardley, S. D. (2003), 'Perceptions/comparisons: Voluntary and mandatory pre-employment government training', Journal of European Industrial Training, 27, 7, 341-54. 